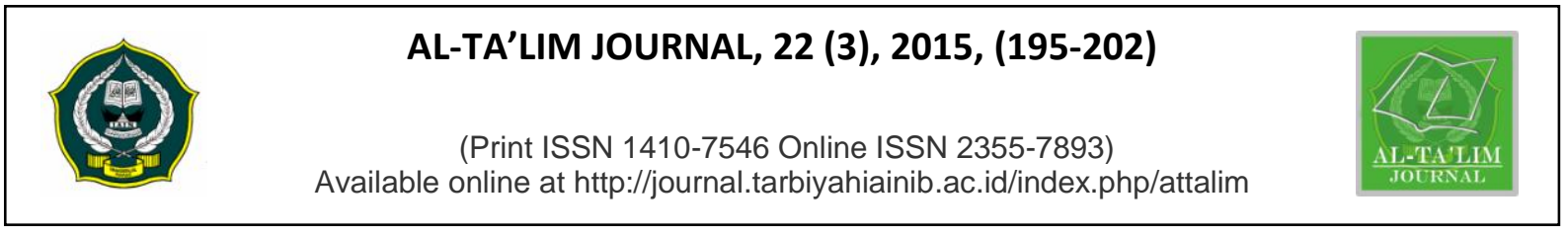

\title{
The Effectiveness of in-service Teacher Training Program at Faculty of Islamic Education and Teacher Training IAIN Imam Bonjol Padang
}

\author{
Hadeli $^{1}$ \\ Department of English, Faculty of Education and Teacher Training \\ IAIN Imam Bonjol Padang, Indonesia \\ Nana Sepriyanti \\ Department of Mathematics, Faculty of Education and Teacher Training \\ IAIN Imam Bonjol Padang, Indonesia \\ ${ }^{1}$ E-mail : ha_deli@yahoo.com
}

Received: $04^{\text {th }}$ August 2015; Revised: 18 ${ }^{\text {th }}$ August 2015; Accepted: 24 ${ }^{\text {th }}$ September 2015

\begin{abstract}
The purpose of this research is to reveal: 1. The influence of in-service Teacher Training Program (PLPG) towards the teacher competency as participant of PLPG; 2 . The correlation between gender $\left(\mathrm{X}_{1}\right)$ towards the teachers' competency as participant of PLPG; .3. The correlation between Age $\left(\mathrm{X}_{2}\right)$ towards the teachers' competency as participant of PLPG; 4. The correlation between years of service towards the teachers' competency as participant of PLPG; 5 . The correlation between the number of training followed $\left(\mathrm{X}_{4}\right)$ towards teachers' competency as participant of PLPG; and 6. This research used quantitative method. The population of this research is 1.300 teachers of PLPG in 2013. By using Yamane formulation, there are 220 teachers taken as the sample. The data was analyzed by using $t$ test and correlation analysis. The findings of the study suggested that: 1. There is a positive influence of PLPG implementation towards teachers' competency as PLPG participant; 2. There is no significant correlation between gender $\left(\mathrm{X}_{1}\right)$ and teachers' competency as PLPG participant; 3. There is a significant correlation between Age $\left(\mathrm{X}_{2}\right)$ towards teachers' competency of PLPG; 4. There is no significant correlation between the Years of Service $\left(\mathrm{X}_{3}\right)$ towards teachers' competency as the participant of PLPG; 5. There is a significant correlation between the number of Diklat followed $\left(\mathrm{X}_{4}\right)$ towards teachers' competency as the participant of PLPG; and 6. There is a significant correlation between the effectiveness of PLPG $\left(\mathrm{X}_{5}\right)$ towards teachers' competency as the participant of PLPG.
\end{abstract}

Keywords: PLPG, LPTK, teacher certification

How to Cite: Hadeli, H., Sepriyanti, N., \& Sepriyanti, N. (2015). The Effectiveness of in-service Teacher Training Program at Faculty of Islamic Education and Teacher Training IAIN Imam Bonjol Padang. Al-Ta Lim, 22 (3). doi:http://dx.doi.org/10.15548/jt.v22i3.120

Permalink/DOI: http://dx.doi.org/10.15548/jt.v22i3.120

\section{INTRODUCTION}

The existence of teacher is so crucial in improving the quality of human resources. Teacher is the main actor who directly face the students, so that teachers play an important role to increase the quality of education and to reach the goal of education. In other word, it can be said that teacher is the key for the success of education and for the accomplishment of education goal. Since, no 
matter how good and how complete the curriculum are, the method, the media, the source, the facilities and the infrastructure, and, the success of education at school is depend on teacher performance. It means that, the students will be qualified if handled by professional teachers.

The main concern of educational issue right after the passed of Law Number 14 of 2005 about teacher and lecturer on December 2005 is teacher certification problem. The initial idea of certification is to improve the quality of education as a whole. Based on the mandate of Law Number 14 of 2004 about Teacher and Lecturer which stipulates the qualification, competency, and certification as a united effort to empower teachers. Hence, this program should be viewed as an effort to improve the teacher profession competency, not merely as a legalization. Therefore, this process should be done thorough and meticulous, so that it would not decrease the quality of the teacher. By the uniformity of teacher quality standard through teacher certification program, it can be assumed that the model of teacher education preparedness has failed in preparing the reliable candidate educators.

The Faculty of Islamic Education and Teacher Training, IAIN Imam Bonjol Padang is one of organizer of teacher certification program LPTK under The Ministry of Religious since 2007 and 2013 is the seventh year. According to the study result of teacher certification implementation and supported by some studies on the previous teacher tarbiyah certification implementation, there are some changes in 2013 on the implementation of teacher certification, the basic change is on the implementation of initial competency testwhich aimed to improve and assure teacher preparedness in following the teacher education and profession training (PLPG), serve as selection tool and also as participant teacher competency mapping of PLPG 2013. The teacher who can pass the intial competency test will be part of PLPG, because the teacher who canget the professional teacher certification is the one who succeed in the initial competency test, PLPG, and The Final Competency Test.

After following PLPG, a teacher should be a professional which characterized by professional teacher certificate, one of the indicators is how to make the research result contributes to the possess of professional ability, one of the indicators can be seen from the result of Intial Competency Test (CT) in the Indonesian term) and the Final UK (Competency Test) .

According to Makmun (2007), there are three learrning components: (1) raw input related with training participants, with all the characteristics keep improving itself through many learning activities, (2) instrumental input, overall, related with instructor and facilities and infrastructure, also include the method, the technique, the media, the learning material, the program, the learning facility, and training implementation leadership, (3) environmental input related to the condition of learning environment, such as social environment, physics culture, etc. The individual characteristic of PLPG partcipant is the different of each participant which influence their competency.

The purpose of this research is to reveal:

1. The influence of PLPG implementation toward the teacher competency as participant of PLPG at LPTK of the Faculty of Islamic Education and Teacher Training, IAIN Imam Bonjol Padang. The correlation between gender $\left(\mathrm{X}_{1}\right)$ toward the teacher competency as participant of PLPG at LPTK of of the Faculty of Islamic Education and Teacher Training, IAIN Imam Bonjol Padang (Y).

2. The correlation between Age $\left(X_{2}\right)$ toward the teacher competency as participant of PLPG at LPTK of of the Faculty of Islamic Education and Teacher Training, IAIN Imam Bonjol Padang (Y).

3. The correlation between Years of Service toward the teacher competency as participant of PLPG at LPTK of the 
Faculty of Islamic Education and Teacher Training, IAIN Imam Bonjol Padang (Y).

4. The correlation between the number of Diklat followed $\left(\mathrm{X}_{4}\right)$ toward the teacher competency as participant of PLPG at LPTK of the Faculty of Islamic Education and Teacher Training, IAIN Imam Bonjol Padang (Y).

5. The correlation between the effectivity of PLPG implementation $\left(\mathrm{X}_{5}\right)$ toward the teacher competency as participant of PLPG at LPTK of the Faculty of Islamic Education and Teacher Training, IAIN Imam Bonjol Padang.

\section{METHOD}

This is a quantitative research and it an expose-facto methodology. The expose $t$ facto research is aimed to see what has happened and then look backward through the data in order to find the initial factors or in order to determine the possible causes on the observed event. There are two variables in this research, the independent variable which consists of Gender $\left(\mathrm{X}_{1}\right)$, Age $\left(\mathrm{X}_{2}\right)$, Years of Service $\left(\mathrm{X}_{3}\right)$, and the effectivity of PLPG implementation $\left(\mathrm{X}_{5}\right)$, meanwhile the dependent variable is teacher competency/ the Result of Final Competency (Y). The population of this research is all participant teachers of PLPG in 2013. The number of the population is 1.300 people which consists of 650 PAI (Islamic Education) teacher and 650 MI (Islamic elementary school) teacher.According to the amount of population taken, hence, in order to determine the representative sample and closer to the existing population, the researcher then used Yamane formulation. By using the formulation, there are 220 people were taken as the sample. The data gathered was analyzed by using $t$ test for the formulation of the problem number 1and correlation analysis used for the formulation of the problem number 2, 3, 4, 5 and 6 . This technique is aimed to test each hypothesis with analysis stages. Before using this technique, it is important to implement some test required.

\section{RESEARCH FINDINGS AND DISCUSSION}

The influence of PLPG towards Teachers' Competency as the Participant of PLPG at LPTK of the Faculty of Islamic Education and Teacher Training, IAIN Imam Bonjol Padang

T-test was used to see whether there is an influence of PLPG implementation towards teacher competency as PLPG participant at LPTK of the Faculty of Islamic Education and Teacher Training, IAIN Imam Bonjol Padang. The Hypothesis of the research is as follows:

Ho: The mean of Competency Test score before and after PLPG is identical.

$\mathrm{H}_{1}$ : The mean of Competency Test score before and after PLPG is not identical.

Reject $\mathrm{H}_{0}$ if the probability is $<0.05$.

Table 1: Paired Samples Statistics

\begin{tabular}{|c|c|c|c|c|}
\hline & Mean & $\mathbf{N}$ & $\begin{array}{l}\text { Std. } \\
\text { Deviation }\end{array}$ & $\begin{array}{l}\text { Std. } \\
\text { Error } \\
\text { Mean }\end{array}$ \\
\hline 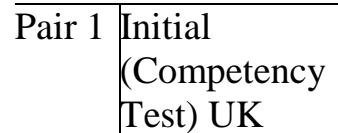 & 28.477 & 220 & 5.065 & 0.342 \\
\hline \begin{tabular}{|l|} 
Final \\
(Competency \\
Test) UK
\end{tabular} & 54.979 & 220 & 5.898 & 0.398 \\
\hline
\end{tabular}


The paired sample statistics shows the summary of mean and standard deviation of both comparisons. The teacher initial CT (Competency Test) mean score is
28.477. Meanwhile, after following PLPG, the teacher final CT (Competency Test) mean score is increasing to 54.979 .

Table 2: Paired Samples Correlations

\begin{tabular}{ll|r|r|c}
\hline & \multicolumn{1}{|c|}{ N } & Correlation & \multicolumn{1}{c}{ Sig. } \\
\hline Pair 1 $\begin{array}{l}\text { The initial and final UK } \\
\text { (Competency Test) score }\end{array}$ & 220 & 0.318 & 0.000 \\
\hline
\end{tabular}

The output paired sample correlations shows the correlation result between two samples. The correlation represented by 0.318 with probability 0.000 (below 0.05 ).
It means that the correlation before and after following PLPG is real and very tight. Below is the output core of the analysis:

Table 3: Paired Samples Test

\begin{tabular}{c|c|c|c|c}
\hline \multicolumn{2}{c|}{} & T & Df & $\begin{array}{c}\text { Sig. } \\
\text { (2-tailed) }\end{array}$ \\
\hline Pair 1 & $\begin{array}{c}\text { The Score of Intial } \\
\text { Competency Test } \\
(\text { UK) - and the Score } \\
\text { of Final UK }\end{array}$ & $-61,053$ & 219 & 0,000 \\
\hline
\end{tabular}

Table 4: The Correlation between Independent Variable towards Dependent Variable

\begin{tabular}{lllr}
\hline & & & Teacher Competency \\
\hline Spear & & & \\
man & Teacher & Correlation & 1.000 \\
Rho & Competency & Coefficient & \\
& & Sig. (2-tailed) & 220 \\
\cline { 3 - 4 } & Gender & Correlation & 0.037 \\
& & Coefficient & \\
& & Sig. (2-tailed) & 0.581 \\
& N & 220 \\
\cline { 3 - 4 } & Age & Correlation & -0.084 \\
& & Coefficient & 0.2 \\
& Sig. (2-tailed) & 220 \\
\cline { 3 - 4 } & N & -0.061 \\
& Years of & Correlation & 0.365 \\
& Service & Coefficient & 220 \\
\hline
\end{tabular}




\begin{tabular}{llr}
\hline Number of & Correlation & -0.015 \\
Training & Coefficient & \\
& Sig. (2-tailed) & 0.829 \\
& N & 220 \\
\end{tabular}

The output shows that Sig (2 tailed) $=$ 0.000 . It means that the probability is less than 0.05 , so that Ho was rejected and the Competency Test (CT) score right before and after following PLPG is not identical. In other words, the implementation of PLPG is quite effective in order to increase the Final CT or increase the teacher competency. It means that there is influence on the implementation of PLPG toward the teacher competency as participant of PLPG at LPTK of the Faculty of Islamic Education and Teacher Training, IAIN Imam Bonjol Padang.

The Correlation between Gender towards the Teachers' Competency as Participant of PLPG at LPTK of the Faculty of Islamic Education and Teacher Training, IAIN Imam Bonjol Padang

The correlation analysis was implemented between the gender variable and the teacher final UK variable as the participant of PLPG at LPTK of the Faculty of Islamic Education and Teacher Training IAIN Imam Bonjol Padang. The result of the analysis shows that there is no correlation between the two variables. Table 4 shows that, it is based on the P-value (sig.) 0.581 (bigger than alpha value 0.2). It means that the correlation of each variable is not significant or there is no significant correlation between gender and the competency of teacher as participantt of PLPG. It happened due to unequal gender distribution of the respondent. The teachers participated in PLPG were dominated by female teachers $(81.8 \%)$ ). Table 5 shows that there is only 40 male teachers as participants of PLPG (18.2\%).

\section{Table 5: Gender Distribution of the Respondent}

\begin{tabular}{rlrr}
\hline & & $\begin{array}{c}\text { Frequen } \\
\text { cy }\end{array}$ & Percent \\
\hline Va & Male & 40 & 18.2 \\
lid & Female & 180 & 81.8 \\
& Total & 220 & 100 \\
\hline
\end{tabular}

The result of the correlation analysis between the two variables indicated that gender has no correlation with PLPG effectiveness in increasing or decreasing the teacher competency as participant of PLPG. The coefficient score of correlation is 0.037 close to zero, which means that correlation between gender towards teacher competency is very weak. There is another factor, instead of gender which probably correlated with the teacher competency quality as the participant of PLPG.

The Correlation between Age towards the Teachers' Competency as Participant of PLPG at LPTK of the Faculty of Islamic Education and Teacher Training, IAIN Imam Bonjol Padang

The correlation analysis is used to see the relationship between teacher age and teacher competency as PLPG participant at LPTK the Faculty of Islamic Education and Teacher Training, IAIN Imam Bonjol Padang. The analysis result shows that (see Table.4) there is correlation between the two variables. This is based on the P-value (sig.) 0.2 (less than or equal with the alpha value 0.2 ). It means that the correlation of each variable is significant or there is a significant correlation between 
final UK score with the age of teacher as the participant of PLPG.

The correlation analysis result between the two variables indicated that the age factor is related with the effectiveness of PLPG in increasing or decreasing the teacher competence. The higher the age of the PLPG participant teachers, the better competency they have.

The Correlation between the Years of Service towards the Teachers' Competence as Participant of PLPG at LPTK of the Faculty of Islamic Education and Teacher Training, IAIN Imam Bonjol Padang

The correlation analysis was looking at between the years of service variable and the teacher final Competency Test (CT) as the participant of PLPG at LPTK of the Faculty of Islamic Education and Teacher Training IAIN Imam Bonjol Padang. The analysis result shows that there is no correlation between the two variables. Table 4 shows that, based on the P-Value (sig.) 0.365 (bigger than alpha value 0.2). It means that the correlation of each variable is not significant or there is no significant correlation between the CT final score and the Years of Service of PLPG teacher participant. The years of service factor of PLPG teacher participant does not determine the quality of their competency.

The Correlation between the Number of Training Followed towards the Teachers' Competency as Participant of PLPG at LPTK of the Faculty of Islamic Education and Teacher Training IAIN Imam Bonjol Padang

There is no strong correlation between training with the teachers' competency as participant of PLPG. The correlation analysis between the numbers of Training followed variable and the final Competency Test (CT) variable of PLPG teacher participant at LPTK of the Faculty of Islamic Education and Teacher Training, IAIN Imam Bonjol Padang.
The analysis result shows that (see Table.4) there is no correlation between the two variables. It is based on the P-value (sig.) 0.829 (bigger than alpha value 0.2). It means that the correlation of each variables are not significant or there is no significant correlation between final UK score and the number of training followed by the participant before PLPG.

The insignificant correlation between the two variables probably was caused by the unequal distribution of respondent data. Because most of the PLPG participant teacher who follow PLPG, 55.9\%, never before following training, there is only $0.5 \%$ or 1 of 220 PLPG participant teachers ever before following training up to 14 times during the years of service.

\section{The Correlation Between PLPG effectiveness towards the Teachers' Competence as Participant of PLPG at LPTK of the Faculty of Islamic Education and Teacher Training, IAIN Imam Bonjol Padang}

The data used in the correlation analysis as the PLPG effectiveness indicator in increasing the PLPG participant teacher competency is the item total score of respondent questionnaire. Hence, after knowing the correlation between the PLPG implementation effectiveness and the final UK score, the data tabulation will be the next. So that, the frequency of every possibilities answer can be known. The frequency is shown in the form of percentage. It means that every statement item use one table accomplished with the frequency and the percentage. After that, the answer of the questionnaire result would be analyzed and interpreted for each item. The analysis data and interpretation shows that PLPG is effective in increasing teacher competency. 


\section{CONCLUSION AND RECOMMENDATION}

According to the obtained research result after analyzing and discussing the problem of this research, below are some conclusions:

1. There is a positive influence of PLPG towards teacher competency as PLPG participant at LPTK of the Faculty of Islamic Education and Teacher Training, IAIN Imam Bonjol Padang or in other words, the implementation of PLPG is quite effective to increase the teacher competency.

2. There is no significant correlation between gender $\left(\mathrm{X}_{1}\right)$ and teacher competency as PLPG participant at LPLK of the Faculty of Islamic Education and Teacher Training, IAIN Imam Bonjol Padang. It probably happened due to the unequal distribution of respondent gender. Most of the PLPG participant teacher was female teacher $(81.8 \%)$.

3. There is a significant correlation between Age $\left(\mathrm{X}_{2}\right)$ towards the teacher competency of PLPG at LPTK of the Faculty of Islamic Education and Teacher Training, IAIN Imam Bonjol Padang (Y)

4. There is no significant correlation between the Years of Service $\left(\mathrm{X}_{3}\right)$ toward the teacher competency as the participant of PLPG at LPTK of the Faculty of Islamic Education and Teacher Training, IAIN Imam Bonjol Padang (Y).

5. There is a significant correlation between the number of training followed $\left(\mathrm{X}_{4}\right)$ towards the teacher competency as the participant of PLPG at LPTK of the Faculty of Islamic Education and Teacher Training, IAIN Imam Bonjol Padang (Y).

6. There is a significant correlation between the effectiveness of PLPG implementation $\left(\mathrm{X}_{5}\right)$ toward the teacher competency as the participant of PLPG at LPTK of the Faculty of Islamic Education and Teacher Training, IAIN Imam Bonjol Padang (Y).

Below are some recommendation and suggestion based on the research result:

1. LPTK as the organizer of PLPG, should continuously apply innovation in order to increase the implementation of PLPG by both input and process, so that the aim of PLPG to create a professional teacher can be reached.

2. The headmaster and Education Office should empower the teachers who had following PLPG and guiding them to keep implementing innovation in the teaching and learning process.

3. The teacher supposes to keep increasing their professionalism by attending seminar and training.

\section{REFERENCES}

Hoeve. V. (1980). Ensiklopedi Indonesia. Jakarta: Ichtiar Baru Van Hoeve.

Direktorat Jenderal Pendidikan Tinggi Departemen Pendidikan Nasional,Sertifikasi Guru dalam Jabatan Tahun 2009: Rambu-rambu Pelaksanaan Pendidikan dan Pelatihan Profesi Guru (PLPG)

Gufran, G., Mukhadis, A., Putro, S. C. (2011) Pelaksanaan PLPG sebagai wahana pengembangan Dan audit kompetensi dalam sertifikasi gurubidang kejuruan: Jurnal Teknologi dan Kejuruan, 34(2).

Kamus Besar Bahasa Indonesia. (2002). 3th, Cet-2, Jakarta: Balai Pustaka

Makmun, A. S. (2007). Psikologi Kependidikan: Perangkat Sistem Pengajaran Modul. Bandung: PT. Rafika Aditama.

Peraturan Pemerintah Nomor 19 Tahun 2005 tentang Standar Nasional Pendidikan. 
Peraturan Pemerintah Nomor 101 Tahun 2000 tentang Pendidikan dan Pelatihan Jabatan Pegawai Negeri Sipil.

Robbins, P. S. (1996). Organiztional Behavior, Concepts, Controversies, Aplications, Translated by Hadyana Pujaatmaka. Jakarta: PT Buana Ilmu Populer
Sumaryanto, T. (2009). Kajian Pelaksanaan Sertifikasi Guru dalam Jabatan. Retrieved athttp://journal.unnes.ac.id/ index.php/jpp/.

Undang-Undang RI Nomor 20 Tahun 2003 tentang Sistem Pendidikan Nasional. 